\title{
MODEL KOMUNIKASI DA'I DALAM PEMBINAAN ROHANI PADA MANTAN PEKERJA SEKS KOMERSIAL DI KOTA PADANG
}

\author{
Elva Ronaning Roem $^{1)}$ Sarmiati $^{2)}$, Ghina Novarisa ${ }^{3)}$ \\ 1) Jurusan Ilmu Komunikasi FISIP Universitas Andalas; elvarona80@gmail.com \\ 2) Jurusan Ilmu Komunikasi FISIP Universitas Andalas; mia_cc4@yahoo.com \\ 3) Jurusan Ilmu Komunikasi FISIP Universitas Andalas; ghinanovarisa90@ gmail.com
}

\begin{abstract}
ABSTRAK
Salah satu cara mantan PSK untuk diterima dalam masyarakat adalah dengan belajar agama dan mencari para Da'i untuk membantu mereka dalam memahami pentingnya komunikasi agama. Sementara itu bagi para Da'i memberikan komunikasi agama dalam bentuk dakwah juga menjadi nilai lebih untuk berusaha menyelamatkan PSK agar mereka bertaubat dan kembali ke jalan yang benar. Penelitian ini fokus pada fenomena sosial pengalaman komunikasi Da'i dalam memberikan pelajaran dalam bentuk komunikasi agama pembinaan rohani pada mantan PSK di kota Padang. Pengalaman tersebut dilihat dari tiga aspek yaitu komunikasi agama pada mantan PSK dalam pembinaan rohani berdasarkan pengalaman subjektifnya, bentuk interaksi simbolik yang dikonstruksikan Da'i dalam menyampaikan komunikasi agama pada mantan PSK dan bagaimana Da'i mengkonstruksi perilaku komunikasi agama pada mantan PSK setelah berhenti sebagai PSK. Penelitian ini menggunakan metode kualitatif dengan paradigm konstruktifisme. Metode pengumpulan data dengan metode wawancara, observasi dan dokumentasi. Informan penelitian ini adalah da'I dan mantan PSK. Penelitian ini dianalisis dan dibedah dengan teori fenomenologi, interaksional simbolik dan konstruksi realitas. Hasil penelitian ini adalah komunikasi Agama Dai Dalam Pembinaan Rohani Pada Mantan PSK Di Kota Padang dilakukan pertama tahap metode Pembinaan Akhlak, Kedua Tahap transformasi diri dan ketiga Tahap peningkatan kemampuan intelektual. Interaksi simbolik di tunjukkan Dai dalam penyampaian pesan komunikasi melalui lambang verbal yakni lebih ke bahasa. Kontruksi Makna Mantan PSK bagi Dai pada mantan PSK setelah berhenti dari pekerjaan kegiatan prostitusi terselubung adalah bahwa mantan PSK wajib di apresiasi.
\end{abstract}

Kata kunci: komunikasi agama, PSK (Pekerja Seks Komersial), Da'I, interaksi simbolik, konstruksi realitas.

\begin{abstract}
One way of ex-Commercial Sex Workers to be accepted in society is by studying religion and looking for preachers who can help them understand religious communication. Meanwhile, the Da'i provide religious communication through da'wah to try to save ex-Commercial Sex Workers to get the right path. This research focuses on social phenomena about how Da'i's communication experience provides lessons through religious communication of spiritual coaching in former prostitution at Padang City. The experience can be seen from three aspects, namely religious communication of former prostitution in spiritual formation based on subjective experiences, symbolic interaction forms constructed by Da'i in conveying religious communication to ex-prostitutes and how Da'i constructs religious communication behavior in former prostitution after resign as sex worker. This research uses a qualitative method with a constructive paradigm. The data collection method is interview, observation and documentation. The informants of this research are da'I and former prostitution. This research was analyzed and dissected with phenomenological, symbolic interactional theory and reality construction. The results of this study are the communication of the Dai Religion in Spiritual Development in Former Prostitution in Padang conducted the first stage of the Moral Development method, the Second Stage of self-transformation and the third Stage of intellectual capacity building. Symbolic interaction is shown by Dai in communicating communication messages through verbal symbols that is more to language. Construction of the Meaning of Former prostitution by Dai to former prostituses after quitting employment in disguised prostitution is that ex-prostitution must be appreciated.
\end{abstract}

Keywords: religious communication, Sex Workers, Da'I, symbolic interaction, reality construction. 


\section{PENDAHULUAN}

Fenomena PSK di Kota Padang bukanlah sebuah isapan jempol, Hasil penelitian Ikhwan \& Erianjoni (2012) menyebutkan jaringan prostitusi di Kota Padang, memiliki cara tersendiri dalam menjalankan aktifitas bisnis mereka, agar tidak tercium oleh aparat penegak hukum. Salah satunya adalah jaringan-jaringan terselubung yang hingga kini sulit untuk ditemukan secara nyata keberadaan mereka, karena bekerja secara hidden. Akibatnya, mantan PSK dalam kelanjutan hidupnya menemui kesulitan untuk menerima diri dalam keadaannya yang sebenarnya. Masalah kepribadian inilah yang perlu mendapatkan perhatian yaitu kondisi penerimaan diri pada individu yang telah menjadi pelacur. Salah satu cara PSK untuk terus dapat membersihkan diri mereka adalah dengan belajar agama dan mencari para Da'i yang dapat membantu mereka dalam memahami pentingnya komunikasi agama bagi mereka dalam memperbaiki hidup. Sementara itu bagi para Da'i memberikan komunikasi agama dalam bentuk dakwah juga menjadi nilai lebih untuk berusaha menyelamatkan PSK agar mereka bertaubat dan kembali ke jalan yang benar.

Pengalaman komunikasi seorang Da'i dalam membina rohani seorang mantan pelacur merupakan pengalaman yang sangat unik. Relis sebuah berita online (www.kompasiana.com), Dakwah secara bahasa berasal dari kata Da'a, Yad'u, $D a$ 'watan yang berarti mengajak, menyeru, atau memanggil. Adapun secara istilah, yang dimaksud dengan dakwah adalah menyeru seseorang atau masyarakat untuk mengikuti jalan yang sudah ditentuan oleh Islam berdasarkan Al Quran dan hadis untuk mencapai kebahagiaan dunia dan akhirat. Dakwah adalah sebuah usaha melalui perkataan dan perbuatan untuk mengajak orang lain kepada da ${ }^{e e} i$, atau kepada perkataan dan perbuatan yang diinginkan dae i. Secara istilah, dakwah bisa dipahami sebagai sebuah usaha mengajak orang lain melalui perkataan dan perbuatan agar mereka mau memeluk Islam, mengamalkan aqidah dan syariatnya (Yusuf, 2011: 9).

Da'i merupakan komunikator dalam penyampaian kegiatan dakwah. Didalam pengajian bersama seorang mantan PSK Da'i sering terlibat komunikasi dengan audiencenya yakni mantan PSK tersebut. Proses komunikasi yang terjadi dalam pengajian dapat berlangsung secara satu atau dua arah. Komunikasi satu arah terjadi pada saat Da'i menyampaikan materi dakwahnya kepada mantan PSK sebagai audience dalam pengajian tersebut. Bila seorang Da'i tidak memiliki kemampuan komunikasi atau tidak memahami proses komunikasi yang baik, maka pesan-pesan dakwah yang akan disampaikan kepada mantan PSK tidak akan berjalan secara efektif. Oleh karena itu da'i memerlukan strategi dakwah adalah keseluruhan keputusan kondisional tentang tindakan yang akan dijalankan, guna mencapai tujuan. Merumuskan strategi dakwah, berarti memperhitungkan kondisi dan situasi (ruang dan waktu) yang dihadapi di masa depan, guna mencapai efektifitas atau mencapai tujuan dakwah (Anwar Arifin. 2011: 237). Sebelum melakukan kegiatan dakwah, seorang da $i$ perlu merumuskan strategi yang tepat untuk keefektifan dakwah. Seorang da ${ }^{e c i}$ harus tahu kapan waktu yang tepat 
menyampaikan pesan inti dakwahnya, karena saat yang tepat itulah seseorang siap menerima wejangan dari inti pesan dakwah yang disampaikan oleh dae $i$.

Bagi para Da'i memberikan dakwah dalam bentuk komunikasi agama bagi mantan PSK sebagai upaya untuk mencegah dampak negatif agar mantan PSK benar-benar insaf dari kegiatan prostitusi tersebut baik secara preventif maupun kuratif. Penerapan dakwah yang dilakukan para praktisi dakwah dengan menggunakan strategi dakwah yang tepat pengalaman komunikasi Da'i inilah yang akan dilihat melalui interkasi simbolik dalam pesan-pesan komunikasi yang dilakukannya padan mantan PSK untuk menanggulangi budaya seks bebas, maka perlu menggalakkan strategi dakwah melalui para tokoh agama dan tokoh masyarakat.

Penelitian ini menitik beratkan perhatian kepada fenomena sosial yang terjadi di Kota Padang tentang bagaimana pengalaman komunikasi Da'i dalam memberikan pelajaran dalam bentuk komunikasi agama pembinaan rohani pada mantan PSK dari dunia prostitusi dan berusaha agar bisa kembali ke jalan yang lurus dan hidup berdampingan dengan masyarakat tanpa beban dan stigma yang kelam. Berdasarkan fokus penelitian tersebut dapat dijabarkan jadi beberpa pertanyaan penelitian yaitu : Bagaimana Da'i melakukan komunikasi agama pada mantan PSK dalam pembinaan rohani berdasarkan pengalaman subjektifnya? Bagaimana bentuk interaksi simbolik yang dikonstruksikan Da'i dalam menyampaikan komunikasi agama pada mantan PSK?, dan Bagaimana Da'i mengkonstruksi perilaku komunikasi agama pada mantan PSK setelah menjadi manusia yang bertaubat berhenti dari pekerjaan kegiatan prostitusi terselubung?

Kontribusi utama dari penelitian ini adalah membuka jalan untuk membangun konstruksi ilmu pengetahuan tentang salah satu aspek agama dan kebudayaan yang sangat berpengaruh kepada berbagai aspek kebudayaan lainnya yaitu pentingnya penggunaan komunikasi sebagai akses informasi dalam merubah karakter serta moral seseorang menjadi lebih terutama bagi mantan perempuan seks komersial. Luaran lain yakni menciptakan model pengalaman komunikasi seorang Da'i dalam melakukan pembinaan rohani pada mantan PSK yang nantinya bisa dipakai dan diimplementasikanpada Peemrintah Kota Padang sebagai role model dalam upaya pembinaan prilaku menyimpang di Kota Padang.

Fenomenologi sebagai teori, menekankan esensi pengalaman. Hal ini merujuk pada pemikiran Edmund Husserl bahwa fenomenologi merupakan teori yang berbentuk deskriptif yang akhirnya memuat esensi dari pengalaman transadental murni yang memiliki justifikasi sendiri (Mc. Can dalam Hafiar, 2012: 32). Dengan demikian, di dalam penelitian ini yang menjadi titik perhatian peneliti adalah esensi dari pengalaman seorang Da'i dalam memberikan pembinaan mental bagi mantan perempuan seks komersial yang berkaitan dengan proses kontruksi makna dalam cara Da'i mempergunakan komunikasi agama untuk membantu mantan PSK agar percaya diri dalam melanjutkan hidup mereka dalam kehidupan normal di masyarakat. 
Konsep Self (diri) terjadi saat individu melakukan internalisasi. Diri akan berkembang dan mulai belajar peranan. Paloma menyebutkan, individu akan melakukan penyesuaian peranan secara sadar sehingga dapat muncul alam perspektif orang lain yang terkait dengan peranannya. Kesaaran ini akan muncul seiring dengan interaksi yang dilakukan individudan interaksi akan melibatkan simbol yang dimaknai secara sibjektif oleh individu (Poloma, 2007: 257).

Pemaknaan konsep diri senada seperti yang diungkapkan Carl Rogers. Menurut Carl Rogers, dalam fenomenologi konsep diri berhubungan dengan pembentukan kepribadian dan penetapan prilaku individu (Burns dalam Hafiar, 2012: 47). Menangkap penikiran Rogers tersebut, maka dapat dikatakan bahwa setiap Perempuan seks komersial dalam hidup dan dunianya bersifat personal dan subjektif dan konsep diri tersebut terbentuk melalui interaksidan lingkungan.

Berdasarkan penjelasan tersebut, melalui proses interaksi yang panjang dan berkesinambungan dijalani oleh mantan Perempuan seks komersial saat berinteraksi dengan lingkungannya. Pemaknaan tentang konsep diri yang dimiliki mantan Perempuan seks komersial ini selanjutnya akan mengembang dalam diri mereka, selanjutnya konsep diri inilah yang menjadi landasan bagi pemunculan motif dari setiap tindakan yang diambil mantan Perempuan seks komersial termasuk keputusannya untuk memilih berhenti bekerja di dunia Prostitusi sebagai Pekerjanya.

Selain itu, Komunikasi yang dilakukan oleh Da'i dalam membina mental rohani mantan Perempuan seks komersial mau tak mau juga membuat Da'i juga harus memahami bagaimana komunikasi sosial yang harus dibangun pada mantan Perempuan seks komersial terhadap lingkungan sekitarnya. Pesan-pesan yang dikelola mantan Perempuan seks komersial pada penelitian ini akan terlihat dalam perilaku komunikasi yang terjadi pada diri mereka ketika komunikasi yang terjadi pada diri mereka dan Da'i dalam ursan sprirituil. Artinya komunikasi yang terjadi dalam diri perempuan seks komersial memiliki makna pada perilaku yang mereka tunjukkan ketika berkomunikasi pada Da'i.

Asumsi yang dibangun dalam menjelaskan perilaku komunikasi yang terjadi pada perempuan seks komersial dimungkinkan bahwa mereka memiliki beragam subbudaya- yang unik dibandingkan dengan subbudaya yang lain. Salah satu keunikan tersebut yang akan peneliti konstruksi misalnya dengan mengamati bagaimana Da'i melakukan pembinaan pada mantan Perempuan seks komersial dengan mengedepankan komunikasi interpersonal agar mantan PSK tersebut memahami setiap pesan agama yang diberikan Da'i dalam praktik komunikasi agamanya pada mantan PSK.

Berdasarkan uraian ini fenomena pengalaman komunikasi yang terjadi pada setiap orang tidak bisa di prediksi. Dan pola pikir yang bersifat sementara ini dapat berubah atau berganti sesuai dengan kondisi waktu yang terjadi dalam penelitian. Kedua, bahwa Da'i dan mantan perempuan seks komersial merupakan fenomena dari sebuah bagian kebudayaan yang unik. Pemaknaan mereka atas realitas yang ada, mulai dari profesi yang berbeda yakni satu sebagai pendakwah dan yang lain adalah mantan i penjaja seksualitas terselubung dan berbayar terbentuk dari berbagai macam faktor, 
namun secara subjektif apa yang ada dalam diri mereka dapat diamati dan menjadi bagian dari sebuah dunia realitas terbungkam dari sebuah sistem sosial yang mereka bangun.

Dengan demikian bahwa Da'i dan mantan perempuan seks komersial merupakan fenomena dari sebuah subkultur yang unik. Pemaknaan mereka atas realitas sosial seperti dunia adalah tempat tinggal sementara di dunia, simbol-simbol yang memiliki istilah sendiri dan perilaku komunikasi hanya dapat dieksplorasi melalui rekonstruksi pengalaman Da'i dan mantan elaku seks komersial itu sendiri.

\section{METODE}

Peneliti menggunakan metode kualitatif, dengan menggunakan paradigma konstruktivisme karena ingin mengungkapkan bagaimana pengalaman yang dimiliki oleh Da'i dalam memberikan pembinaan rohani pada mantan PSK di Kota Padang. Melalui paradigma konstruktivisme, peneliti membaca, memetakan, dan menganalisis bagaimana konstruksi komunikasi interpersonal yang dibangun oleh seorang Da'i dalam memberikan ketenangan rohani pada mantan PSK di Kota Padang. Dengan menggunakan paradigma konstruktivisme peneliti juga akan membangun sebuah model komunikasi model komunikasi da'i dalam pembinaan rohani pada mantan pekerja seks komersial di kota Padang.

Adapun dalam penelitian ini, peneliti menetapkan kriteria untuk memilih informan penelitian, yang meliputi: (1) Da'i yang pernah memberikan ceramah agama islam terkait pembekalan Rohani pada PSK. (2) PSK yang sudah berhenti menjadi pelacur. Pada penelitian ini peneliti mewawancarai enam orang informan. Adapun yang dijadikan informan penelitian adalah tiga orang Da'i yang sudah berpengalaman dalam memberikan pembekalan rohani terutama tentang pelajaran agama kepada para PSK dan 3 Orang mantan PSK yang telah berhenti menjadi Pelacur. Teknik pengambilan informan pada penelitian ini menggunakan teknik purposive sampling. Peneliti telah menetapkan enam informan sesuai dengan kriteria yang sudah ditetapkan sebelumnya. Peneliti menggunakan teknik triangulasi data untuk menunjukkan bukti empirik dalam meningkatkan pemahaman terhadap realitas yang diteliti. Teknik tirangulasi data ini dilakukan dengan mewawancarai, mengamati, dan membandingkan perspektif dari berbagai informan mengenai komunikasi interpersonal yang dilakukan oleh para informan.

\section{HASIL DAN DISKUSI}

\section{Metode Komunikasi Pembinaan Akhlak}

Metode dakwah adalah cara-cara penyampaian ajaran Islam kepada Individu, kelompok ataupun masyarakat supaya ajaran itu dengan cepat dimiliki, diyakini serta dijalankan (Alwisral: 2005: 71). Salah satu metode dakwah yang dilakukan Dai dalam penelitian ini adalah metode pembinaan akhlak dengan membina akhlak mantan PSK 
yang berproses Mengingatkan kembali pada dirinya bahwa pembinaan ahklak akan menghasilkan perbuatan yang baik kepada manusia sehingga menghasilkan kebaikan dan kebahagiaan pada seluruh kehidupan manusia, lahir dan batin.

Pengalaman-pengalaman yang dimiliki Dai dalam melakukan pembinaan rohani pada mantan PSK tak lain adalah untuk mengajarkan bahwa sebagai orang yang pernah masuk dalam dunia prostitusi dan ketika insaf maka yang dituntut dari diri mantan PSK tersebut adalah, sikap adil, jujur, kasih sayang dan menghormati kepada sesama, ikhlas. Pembinaan akhlak lanhkah pertama yang harus ditanamkan pada mantan PSK, dengan menyadarkan bahwa kehidupan ini sesungguhnya tidak lah semulus yang dibayangkan Kehidupan yang diwarnai oleh permusuhan, konflik, saling menjatuhkan, hasut menghasut, fitnah memfitnah, dan semacamnya adalah bersumber dari sikap terpuji tersebut belum dimiliki oleh banyak orang. Dan para mantan PSK sudah merasakan hal itu ketika mereka berada dalam dunia prostitusi pada masa lalunya.

Bagi Dai dalam penelitian ini siapapun akan berpandangan sama, bahwa nilai-nilai mulia tersebut memang penting diberikan atau dididikkan pada mantan PSK yang ingin kembali pada jalan yang lurus. Berbagai sikap mulia tersebut tidak akan dimiliki begitu saja tanpa melewati proses pengetahuan Kejujuran, keadilan, yang harus ditanamkan dan dididikkan dari waktu ke waktu. Namun pertanyaannya adalah bagaimana menanamkan sikap mulia itu. Akhlak mulia akan lahir dari orang atau sekelompok orang yang berakhlak mulia, dan demkikian pula sebaliknya. Selain itu, pendidikan akhlak tidak cukup dilakukan dengan cara menjelaskan tentang pentingnya akhlak mulia. Banyak orang mengetahui tentang pentingnya disiplin, menghargai orang lain, jujur, adil, dan lain-lain tetapi pada kenyataannya orang yang mengetahui dan memahami nilai-nilai mulia tersebut tidak selalu mampu menjalankannya dalam kehidupan sehari-hari.

\section{Metode Komunikasi Bimbingan dan Konseling}

Secara etimolologi kata guid memiliki arti mengarahkan, memandu, mengelola. (Syamsu, 2009: 37). Metode bimbingan dan konseling yang dilakukan oleh Dai dalam penelitian ini adalah dengan cara memberikan, dakwah yang memuat arti kegiatan mengkomunikasikan pesan ajaran Islam kepada mantan PSK, mengindikasikan bahwa kegiatan dakwah merupakan bentuk dari komunikasi. Komunikasi itu sendiri secara sederhana bermakna suatu proses penyampaian pesan dari penyampai pesan (komunikator) kepada orang lain (komunikan). Seperti halnya pengertian dakwah yang sederhananya berarti menyeru dan menyampaikan pesan ajaran Islam kepada khalayak. Dalam hal ini pesan yang diberikan adalah pesan yang membuat mantan PSK bisa membuka pemikirannya bahwa kembali kejalan yang lurus harus benar-benar istiqamah. Namun tentu tidak terbatas pada makna penyampaian saja, baik komunikasi maupun dakwah mengandung maksud pesan yang disampaikan akan mendapat respon 
(feedback) dari mantan PSK tersebut baik berupa penerimaan dan pemahaman maupun tindakan.

\section{Model Komunikasi Dakwah Pendekatan.}

Model komunikasi pendekatan dakwah adalah suatu gambaran atau pola penyampaian pesan dakwah oleh dai (komunikator) berupa ajaran Islam yang dilkukan untuk mengajak mantan PSK agar berperilaku dan berbuat baik sesuai dengan ajaran Islam, baik daalam bentuk verbal maupun non verbal, kepada mantan PSK yang sangat memperhatikan tatanan komunikasi untuk dapat mengatasi perbedaan kultur.

Belajar solat sangat penting bagi mantan PSK. Dai selalu menyampaikan dengan bahasa verbalnya bahwa dengan mendirikan shalat secara khusyuk bagi mereka maka akan dihapuskan kesalahan dan penolak beragam keburukan. Shalat adalah tiang agama dan Amalan yang dihitung pertama kali. Dan para Mantan Dai selalu diingat bahwa Pada hari kiamat nanti amalan yang pertama ditanya adalah shalatnya. Jika shalat seseorang tersebut baik, tentu amalan yang lain juga baik dan dia akan beruntung sedangkan jika shalatnya rusak dia akan rugi dan gagal.

Berikut gambar model komunikasi agama yang diberikan oleh Dai dalam pembinaan mental mantan PSK di kota Padang:

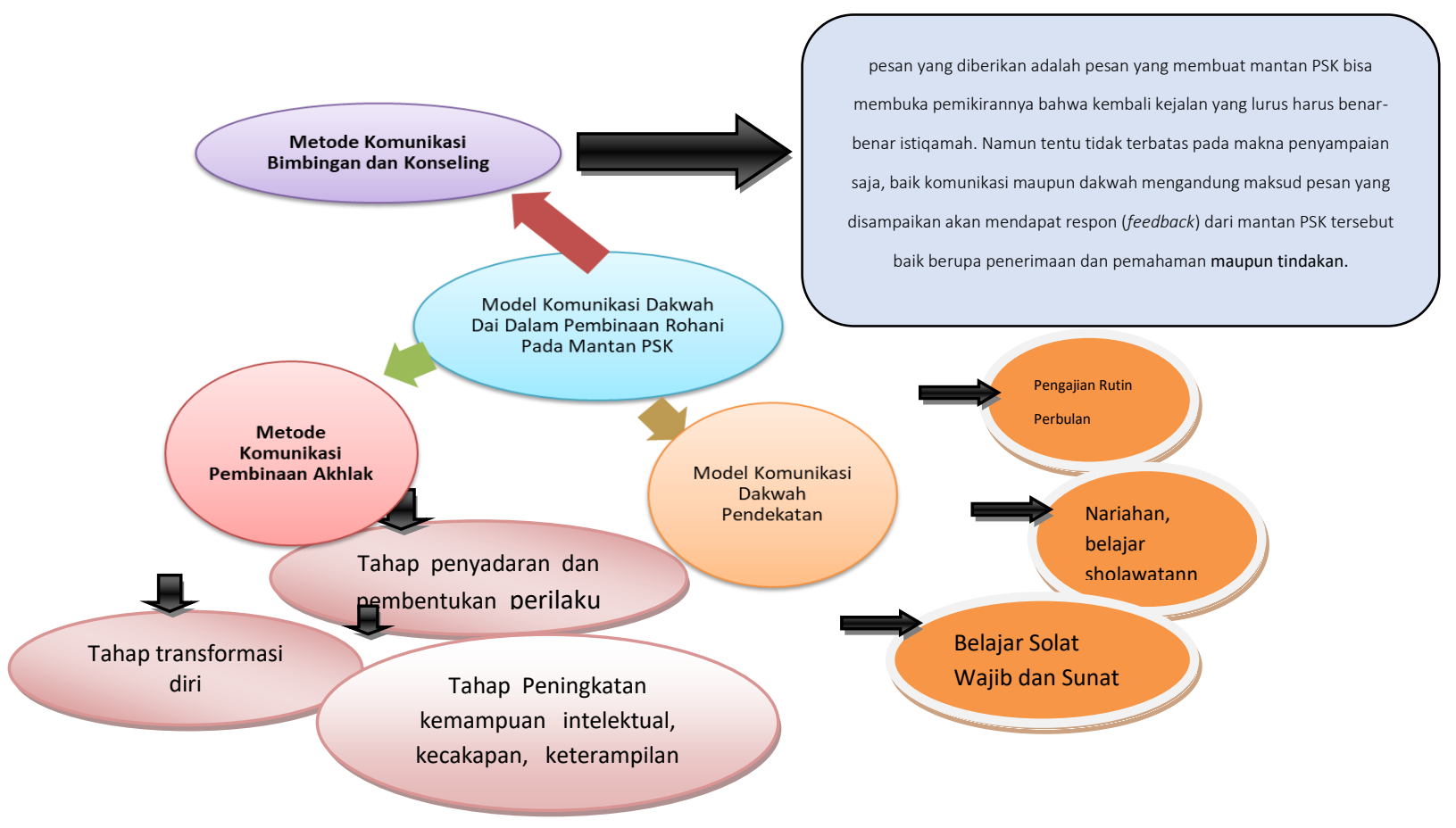

Gambar 4.1

Model Komunikasi Dakwah Dai dalam pembinaan Rohani Mantan PSK Di Kota Padang

Sumber: Hasil Penelitian 2019 
Interaksi simbolik Dai dalam menyampaikan komunikasi agama pada mantan PSK.

Konsep teori interaksi simbolik ini diperkenalkan oleh Herbert Blumer sekitar tahun 1939. Teori interaksi simbolik sesungguhnya masih berada dalam payung persepktif fenomenologis yang mengasumsikan bahwa orang bertindak berdasarkan makna simbolik yang muncul dalam sebuah situasi tertentu, sedangkan simbol adalah representasi dari sebuah fenomena, dimana simbol sebelumnya sudah disepakati bersama dalam sebuah kelompok dan digunakan untuk mencapai sebuah kesamaan makna bersama (West \& Turner, 2008: 98).

Dalam interaksi simbolik yang ditunjukkan Dai dalam pembinaan rohani PSK dalam kesehariannya, mereka juga memiliki persepsi tentang bagimana identitas diri yang muncul dalam balutan konsep diri yang menjadi prinsip bagi Dai untuk menampilkan diri mereka. Sementara itu bahasa atau komunikasi melalui simbol-simbol adalah merupakan isyarat yang mempunyai arti khusus yang muncul terhadap individu lain yang memiliki ide yang sama dengan isyarat-isyarat dan simbol-simbol akan terjadi pemikiran (mind). Manusia mampu membayangkan dirinya secara sadar tindakannya dari kacamata orang lain, hal ini menyebabkan manusia dapat membentuk perilakunya secara sengaja dengan maksud menghadirkan respon tertentu dari pihak lain.

Selain itu interaksi simbolik juga ditunjukkan melalui pengelolaan kesan seperti Dai juga harus menyampaikan pesan melalui lambang verbal yakni menggunakan bahasa. Interaksi simbolik yang dimaksud dalam hal ini adalah pemaknaan terhadap suatu hubungan yang terjadi secara alami antara Dai dan mantan PSK dalam pengajian. Interaksi yang bersifat simbolik tersebut berkembang melalui simbol-simbol yang mereka ciptakan. Interaksi yang dilakukan Dai pada mantan PSK berlangsung secara sadar dan berkaitan dengan penyampaian bahasa yang harus menggena pada kognitif mantan PSK ketika berceramah agama. Kesemuanya itu mempunyai maksud dan disebut dengan "simbol". Adapun hasil pemaknaan interaksi simbolik tersebut adalah:

\section{Bahasa Permintaan Tolong}

Bahasa merupakan suatu ungkapan yang mengandung maksud untukmenyampaikan sesuatukepada orang lain. Sesuatu yang dimaksudkan olehpembicara bisa dipahami dan dimengerti oleh pendengar atau lawan bicaramelalui bahasa yang diungkapka Chaer dan Agustina (1995:14) fungsi utama bahasa adalah sebagai alat komunikasi. Hal ini sejalan dengan Kridalaksana (2008: 28-29) mengartikan bahasa sebagai suatu sistem lambang arbitrer yang menggunakan suatu masyarakat untuk bekerja sama,berinteraksi, dan mengidentifikasikan diri.

Bahasa pertolongan merupakan serangkain simbol yang digunakan oleh Dai yang digunakan untuk menyampaikan permintaan tolong, pada mantan PSK agar dalam kehidupan ini lebih selalu banyak bersyukur. Perilaku simbolik ini dapat 
diketahui karena adanya interaksi sosial yang bertujuan untuk menyampaikan suatu pesan kepada orang lain.

\section{Membangun Pandangan Positif pada Mantan PSK}

Keberadaan agama pada dasarnya berfungsi sebagai pembimbing hidup manusia agar lebih baik dan lurus yang sesuai dengan nilai-nilai kemanusiaan. Agama juga mengajarkan bagaimana tata hidup, baik sebagai pribadi maupun sosial. Namun dalam perjalanannya tidak semua manusia yang beragama paham dan melaksanakan ajaranajaran agama yang diyakininya. Mantan PSK adalah bagian dari makhluk sosial yang perlu diapresiasi karena kesadarannya untuk memilih berhenti dari pekerjaan kotor dan beralih menjadi manusia yang normal. Namun menuju kebaikan ada berbagai faktor yang menyebabkan mantan PSK tidak mampu menjalankan hidup sesuai dengan ajaran agama yang dipeluknya dan semuanya perlu proses melalui pembinaan rohani yang diajarkan para Dai tersebut tentang pelajaran agama agar percaya diri dalam kehidupan sosialnya.

Sebagaimana realitas hidup para mantan PSK, berusaha meyakini agama sebagai pedoman hidup dan mengetahui perintah-perintah serta larangan-larangan agama yang harus dijalaninya, namun adanya berbagai kondisi yang menghimpit mereka serta pengaruh sosial yang dijalani, mereka dengan terpaksa ataupun secara sadar meninggalkan ajaran-ajaran agama tersebut. Dan hal itulah yang menjadi Pekerjaan spiritual bagi Dai untuk melakukan pembinaan rohani pada mantan PSK agar selalu terus mengingat sang Kholiqnya.

\section{Kontruksi Makna Mantan PSK bagi Dai pada mantan PSK setelah berhenti dari pekerjaan kegiatan prostitusi terselubung.}

Salah satu teori yang masih berada dalam payung fenomenologis adalah teori Konstruksi Sosial atas Realitas yang di bawa oleh Peter Berger dan Thomas Luckmann (1975:70). Konstruksi Sosial atas Realitas (Social Construction of Reality) didefinisikan sebagai proses sosial melalui tindakan dan interaksi dimana individu atau sekelompok individu, menciptakan secara terus-menerus suatu realitas yang dimiliki dan dialami bersama secara subjektif (Bungin, 2008: 15). Teori ini berakar pada paradigma konstruktivis yang melihat realitas sosial sebagai konstruksi sosial yang diciptakan oleh individu, yang merupakan manusia bebas. Individu menjadi penentu dalam dunia sosial yang dikonstruksi berdasarkan kehendaknya, yang dalam banyak hal memiliki kebebasan untuk bertindak di luar batas kontrol struktur dan pranata sosialnya. Dalam proses sosial, manusia dipandang sebagai pencipta realitas sosial yang relatif bebas di dalam dunia sosialnya.

Sementara itu dalam pemikiran Schutz tentang pemaknaan adalah tentang bagaimana memahami tindakan sosial melalui penafsiran. Proses penafsiran makna dapat digunakan untuk memperjelas atau memeriksa makna yang sesungguhnya, sehingga dapat memberikan konsep kepekaan yang implisit. Schutz melatakkan hakikat 
manusia dalam pengalaman subjektif terutama ketika mengambil tindakan dan mengambil sikap terhadap dunia kehidupan sehari-hari.

Seperti yang dituliskan di atas, Husserl dan Shutz sama-sama sepakat bahwa tindakan dilandasi pengalaman, makna dan kesadaran. Namun Schutz juga terinspirasi oleh pemikiran Weber mengenai tindakan sosial yang disebut menekankan faktor makna subjektif yang dilekatkan pada sebuah tindakan yang dilakukan individu berdasarkan pertimbangan yang berorientasi pada perilaku orang lain terhadap tindakannya (Mulyana, 2001: 61), maka Schutz mengembangkan konsep orientasi ini menjadi motif.

Berdasarkan hal tersebut maka dapat dikatakan bahwa pengalaman-pengalaman yang di peroleh mantan pelaku seks komersial saat ia berinteraksi dengan lingkungannya, termasuk pengalaman komunikasi dalam setiap kegiatan prostitusi, akan menjadi suatu pengetahuan yang menghasilkan kesadaran dan pemaknaan akan sesuatu, termasuk makna akan kondisi pekerjaan yang dipilihnya sebagai penjual jasa seksual. Pemaknaan ini merupakan landasan yang menggerakkan pelaku seks komersial untuk mengambil suatu tindakan, misalnya akan berhenti menjadi pelaku seks komersial dengan berbagai alasan yang menyertainya.

Dalam penelitian ini penyebab seorang perempuan memutuskan untuk menjadi PSK antara lain karena faktor desakan ekonomi, lingkungan, berasal dari keluarga yang broken-home, telah bercerai atau sakit hati bisa mengakibatkannya masuk dalam dunia prostitusi. Namun PSK juga bisa berhenti dari profesi dengan alasan tertentu pula. Namun seorang PSK yang menyadarkan diri untuk berhenti dari profesinya wajiblah untuk dihormati da dihargai keputusannya tersebut. Para Dai mengkonstruksi perilaku mantan PSK tersebut sebagai sesuatu yang baik. Bagi Dai Para mantan pelacur itu pada umumnya bukan pencuri. Mereka sama seperti manusia lainnya sebagai warga negara, mereka juga punya hak dan kewajiban yang sama. Mantan PSK tentunya harus dihormati, karena order sosial atau kolektif itu kan berdasarkan order individu, dan bukan sebaliknya. mantan PSK adalah manusia biasa yang seharusnya sebagai sesama manusia seseorang juga tidak boleh melakukan penistaan terhadap mereka. Apakah alasan tersebut karena moral dan kesucian.

\section{KESIMPULAN}

\section{Kesimpulan}

Komunikasi Agama Dai Dalam Pembinaan Rohani Pada Mantan PSK Di Kota Padang dilakukan dengan berbagai tahap yakni pertama tahap metode Pembinaan Akhlak dengan cara pertama Tahap penyadaran dan pembentukan perilaku menuju perilaku sadar dan peduli sehingga merasa membutuhkan peningkatan kapasitas diri. Kedua Tahap transformasi diri kemampuan berupa wawasan pengetahuan, kecakapan, keterampilan agar terbuka wawasan dan memberikan keterampilan dasar sehingga dapat mengambil peran di dalam pembangunan dan ketiga Tahap Peningkatan 
kemampuan intelektual, kecakapan, keterampilan sehingga terbentuklah inisiatif dan kemampuan inovatif untuk mengantarkan pada kemadirian. Sementara itu melalui kedua Metode Komunikasi bimbingan dan konseling melalui pencerahan ilmuilmu agama ayng diberikan saat ceramah berlangsung. Dan ketiga Model Komunikasi Dakwah Pendekatan dengan mengadakan pengajian rutin bulanan, mengajarkan bacaan zikir serta tidak boleh meninggalkan solat wajib serta mengajarkan solat sunat yang penting pelaksaanaannya pada waktu-waktu tertertentu.

Interaksi simbolik Dai dalam menyampaikan komunikasi agama pada mantan PSK di tunjukkan Dai dalam penyampaian pesan komunikasi melalui lambang verbal yakni lebih ke bahasa, karena bahasa merupakan komunikasi verbal menempati porsi besar dalam membangun sebuah komunikasi pada mantan PSK dalam menyampaikan dakwah agar mereka merasa percaya diri dalam menjalani hidup di lingkungan sosial.

Kontruksi Makna Mantan PSK bagi Dai pada mantan PSK setelah berhenti dari pekerjaan kegiatan prostitusi terselubung adalah bahwa mantan PSK wajib di apresiasi karena memutuskan untuk nerhenti total dari pekerjaan melacur dan mantan PSK adalah tetap manusia biasa pada masa lalunya yang masuk dalam kelompok marginal karena keputusan yang salah dalam memilih jalur hidupnya.

\section{Saran}

1. Penelitian ini ditindak lanjuti dengan penelitian-penelitian serupa dengan menggunakan pendekatan dan metode yang berbeda. Misalnya melakukan Focus Grup Discusi (FGD) pada PSK dalam mengungkap perilaku mereka melalui studi kasus dan paradigma postivisme dan kritis agar mantan Pelaku Seks Komersial menyadari bahwa mereka masuk dalam kelompokyang perlu diapresiasi keputusannya meninggalkan perilaku menyimpang dan tersadar untuk segera disembuhkan dari penyakit yang perlu dikritisi dan mendapat perhatian khusus yang harus di prioritaskan.

2. Penulis berharap Pemerintah Kota Padang hendaknya harus merancang model penanggulangan komunikasi efektif dalam hal prostitusi terselubung di Kota Padang, misalnya melakukan program rehabilatasi dalam rumusan yang lebih jelas dalam membina PSK di kota Padang. Program ini tentunya tidak bisa di lakukan secara langsung semuanya berproses dengan melibatkan berbagai Lembaga Sosial Masyarakat (LSM) menggandeng ninik mamak, alim dan ulama dalam menghidupkan "Tigo Tungku Sajarangan" untuk menyelamatkan Provinsi Sumatera Barat dari perbuatan maksiat. Serta melakukan Focus Group Discusion (FGD) pada PSK, mencarikan peluang kerja bagi PSK. Pemerintah Kota Padang juga di harapkan harus menggandeng setiap Universitas yang ada di Kota Padang dalam memonitor perilaku menyimpang yang dilakukan mahasiswa/mahasisiwi dalam urusan prostitusi terselubung yang saat ini banyak di lakoni kaum intelektulitas di perguruan tinggi yang menganggap bahwa menjual jasa beli seksualitas adalah salah satu bisnis yang mengguntungkan. Harapan besar peneliti juga tertumpu pada setiap 
Universitas, hendaknya mulai merancang matakuliah tantang "Moralitas" yang wajib untuk menjadikan output bagi mahasiswa menjadi manusia yang berakhlak mulia dan memiliki moralitas yang tinggi dalam hidupnya.

\section{REFERENSI}

Arifin, Anwar (2011). Dakwah Kontemporer. Yogyakarta: Graha Ilmu.

Ardianto. (2016). Metodologi Penelitian untuk Publik Relation Kuantitatif dan Kualitatif. Bandung: Simbiosa Rekatama Media.

Hafiar, H. (2012). Cacat dan Prestasi Melalui Pengalaman Komunikasi Atlet Penyandang Cacat: Studi Fenomenologi Mengenai Konstruksi Makna Kecacatan dan Status sebagai Atlet Berprestasi Melalui Pengalaman Komunikasi Atlet Penyandang Cacat Berprestasi di Bandung. Unpublished Doctoral Dissertation Padjadjaran University.

Kridalaksana, Harimurti. (2008). Kamus Lingusitik. Jakarta: Gramedia

Mulyana, Deddy. (2001). Pengantar Ilmu Komunikasi, Bandung: Remaja Rosdakarya.

Salim, Peter dan Yenny Salim. (2007). Sosiologi Kontemporer. Jakarta: PT Rajawali Pers.

Syamsu, Yusuf (2009). Program Bimbingan dan Konseling di Sekolah Bandung: Rizqi Press.

Taufiq, Yusuf. (2011). Fiqih Dakwah Ilallah. Jakarta: Al-I"tishom.

West, R., \& Turner, L. H. (2008). Pengantar Teori Komunikasi: Analisis Dan Aplikasi. Jakarta: Salemba Humanika.

West, Richard and Lynn H. Turner. (2008). Introducing Communication Theory. Newyork: Mc. Graw Hill.

Ikhwan \& Erianjoni. (2012). Pola Dan Jaringan Prostitusi Terselubung Di Kota Padang, dimuat dalam Jurnal Humanus Vol. XI No.2 Th. 2012 Hal 112118.Shodiq,

Fajar. Muh dkk. 2018. Pengembangan Sosial Kemasyarakatan Pembinaan Mental Spiritual Bagi Para Mantan Pekerja Seks Komersial (Psk) Di Surakarta Dimuat dalam Jurnal Dakwah Komunikasi, Jurnal al-Balgh. 4. Vol. 3, No. 1, January - June 2018, Hal .10 - 26

Zaidallah, AlwisralImam, (2002). Strategi Dakwah dalam Membentuk Da'i dan Khotib Profesional, Jakarta: Kalam Mulia,

https://www.kompasiana.com/nurjhanna/5583760ef57a613d048b456e/kisah-para-daidalam-berdakwah-di-lokalisasi.

http://id.shvoong.com/humanities/theory-criticism/2035989-pengertianasusila/\#ixzz2hTS5nHeS. Di Akses tanggal 12-Oktober Pukul 10:22. 
E-ISSN : 2656-4718

P-ISSN : 2302-8106

Jurnal Ranah Komunikasi (JRK)

Volume 04 Nomor 01 Tahun 2020

Disarikandari:http://www.academia.edu/3319840/Fenomenologi_Alfred_Schutz_Studi_ tentang_Konstruksi_Makna_dan_Realitas_dalam_Ilmu_Sosial Disarikan dari https://id.wikipedia.org/wiki/Fenomenologi 